る像か？

答 血腫様エコーの説明ではなく, 貯留された血液像 之訂正する。

演題23は, 消化管穿孔発生部位別頻度は十二指腸が最 屯多く, 胃, 結腸の順であり, 遊離ガス像の描出率は胃 穿孔, 十二指腸潰瘍, 結腸穿孔の順で多く, また描出部 位は右横隔膜下が多かった。とのことから腹部単純エッ クス線写真における消化管穿孔時の遊離ガス像の描出率 は高く有用性があるが，乙の描出率は患者の状態にもよ るが撮影上の手技的なものにも左右されると報告した。

有意義な研究発表が多かったが時間的制約もあり, 参 加者個々には明確にできなかったいくつかの閏題点も残 ったように思われた。

撮影 -3

座長 木村金二（富山逓信病院）

\section{4. カーボンシステムの臨床応用についての検討}

三重大学医学部附属病院放射線部

○宮崎幸俊・中西 篤・高田孝広

牧 浩昭・松村佳彦

最近カーボンファイバーの撮影関連具への応用がなさ れて来ている. そこでX線吸収と散乱線特性について検 討を行い, 合せて臨床使用への効果についても検討を行 った。

システム化（グりッドとカセッテ）して使用すると 40 〜 60\%のX線被曝軽減となる. 高コントラスト造影写真 に有効である，画質は撮影条件の改善（管電圧，小焦点， 短時間等）によって向上される，等の結果を得た。

\section{5. 回診用薄型 $\ulcorner$ Carbon cassette $」$ 試作について} 三重大学医学部附属病院中央放射線部

○松村佳彦・宮崎幸俊・牧 浩昭 北野外紀雄・江原 功・中西 篤 高田孝広

回彰用ポータブル撮影の増加に伴ない, 従来のアルミ カセッテでは, 回診用ポータブルの構造上, 収納枚数に 大きな制約があるため, 従来の規格である厚みを $8 \mathrm{~mm}$ 厚に軽減した大角 carbon cassette 老試作した. 実際で の使用より，作業性の改善，収納枚数の增加により，回 診時間の短縮, 患者, 技師, 介助者への被曝量の軽減も はかれ，たわみによる患者への背中への異和感の軽減も はかれた。また，臨床上の画質低下む見い出されなかっ た。

質問 カーボンカセッテの久点として(きれつ, 割れ) が言われるが貴院での試作品では落下テスト等を施行し たかどうか?
その結果はどうであったか。（白鳥）

答 cassette の搬送は belt conveyer で一括してやっ ているので，特に落下テストは行なわれなかった。

普通の状態での普通の衝撃落下では全く異常は認めら れなかった。

\section{6. 陽極側 $\mathbf{X}$ 線錐利用の検討一胃 $\mathbf{X}$ 線検查への応用一} 大垣古民病院放射線科

○鶴田初男・遠藤斗紀雄・川上文浩 高木 等・岩崎浩康・坂野信也 茂木正義・金森勇雄

1） X線管の長軸方向の焦点幅を実測した所，陽極側 に近づくに従って小さくなり, 理論值と良く相関した. 2）より小さい焦点を利用する目的で，管球に角度を付 けて陽極側線錐を利用しても，公称照射野までの範囲で は臨床上の写真濃度に影響はなかった。 3) MTF の評 価においてす, 焦点が小さい程, すなわち陽極側に近い 線錐を利用する程良くなった。4）胃X線検査のように, ぞちらかと言えば写真上で，下半分に横線の要素が多く， かつ下半分に病変の多い検査では，足側に陽極を配し， しかも角度を付けるととにより，さらに鮮鋭度の良い写 真が得られた。

\section{7. 各種 $X$ 線撮影用支持装置の考案 $\mathrm{X}$ 線検查時におけ} る患者心理について一第 2 報「固定」一 名古屋大学医学部附属病院分院放射線科 ○堀部広恵・堀部泰樹

X線検査の中で, 患者整位, 固定, 再現性には最毛多 くの時間を必要とするままた私達の調査においてもX線 検査受彰の患者（幼览）には大別して次の 2 種の患者層 に気付いた． 1 ．患者（幼児）自身が納得している場合 (自己認識型) あるいは何手理解してないが拹力的な場 合 (協力型). 2 . 強制的にのみ検查が遂行される場合 (強制型)，私達は各種支持装置の開発に当り，前述の型 態を充分に考慮し, 目的検查部位の正確な情報の確保, 迅速な情報取得, 正確な再現性等診断領域へのアプロー チと装置等に接する異和感の除去等患者サービスへの向 上の両面を持ち合わせた装置の考案を試み, 多くの成果 と各種の問題点を知見したので報告する.

質問 1 . 胸部固定具の使用対象年鈴は何歳か。 2 . 小児胸部立位撮影時の頭部固定の配慮をされているか. (宮本)

答 (1) 小児の対象年秢は0〜3歳ぐらいとするが，立 位撮影では，映画， animation が理解可能年齢は $2 \sim 3$ 祡 が対象となる。(2) 特に頭部国定はしないが，映画が目 の位置にくるようにするか，親が演技をするととで，充 
分頭部固定の代替えは可能である。

質問 幼児の手の 2 方向撮影に扔いて，側面で指が， 重ならないようにするのにはどうしているのか（倉田)

答 測面撮影においても，airbagで加重しながら押え る.また綿をつめるととあある，当院では，両手同時撮 影を point としている.

\section{8. 救急患者（腹部外傷）に対する放射線室としての技 術的諸問題}

福井県武生市中村病院

○真柄義一, 紙谷興弘・佐々木喜代治

近年, 交通及び学災事故の增加にともない, 救急患者 における腹部外傷患者の占める割合す増加している現状 加, 救急腹部外鹪患者の検查時飞お打る，放射線技師 の問題点を検討した.

1. 撮影室搬入時の患者の全身状態の把握, 2 . 患者 の受診状態による撮影体位・撮影方法および撮影補助具, 3. 患者の全身状態掞よび呼吸状態による撮影条件の設 定，4. 撮影中患者急変時の対応と処置，5. 腹部実質 臓器損傷が疑われる場合の検查の組合わせ，があげられ る.

以上のまとめとして，1，救急患者の全身状態を詳細 に把握するための平常からのトレーニング， 2 ，診断目 的にかなった特に多様化住対応できる技術の確立， 3 . 撮影条件の標準化により, ミスの防止之適確な情報をむ つ写真撮影の実施， 4 . 総合画像晾断の導入にともなう ところの技術の習得と理解， 5 ．撮影中におこりうる患 者の容体の変動汶対処する技術(看謢)の修練である.

\section{座長集約}

本演題群は数年前から医療機材に使用されはじめた， CFRP (Carbon Fiber Reinforced Plastics) を Casette や Grid よど使用した場合の画質などの特性強化に関 する演題 2 題,

X線管陽極線錐の方位制を臨床時胃 X線検査に利用し， その成果を述べたもの 1 題.

臨床時に於ける患者対応に関するむの 2 題であった。

演題24は物理的特性を格子比，管電圧などの関係から 検討している，宮崎らは臨床例をあって，その画質效能 を良しとしてのべている. 今後グリッドの使い分けも重 要となるう。

演題25は，炭素繊維強化樹脂製の cassette の構造上の， 比較検討を行っている. 特にこの cassetteのもつ, 軽量 化を力説し, 回診用ポータブル撮影に有用之説いた. 確 かて軽量化は，乙の材質の特性でああるととから，今後 増々普及はすると思うが，価格の点で今一歩というきら
いがある。

演題 26 は，X 線管陽極利用線錐の方位制を，骨X線 検査に利用した場合の画質の検討を行なったものであ 万。

精度, 画質の点では, Chart試験, Phantom 試験にお いても，足側陽極で角度をつけた方が優れた写真が得ら れたよのでている.

今後は，X線管球自体の保守管理上の問題，あるいは， 立位，臥位時における比較検討の研究を期待したい.

演題27は, 幼児, 小児X線検査時に際しての臨休的患 者心理に一歩踏み込んだ研究としては，乙の種の学会で は特異の部類に入れられるものと思う。

今回は幼咒に限定しての研究ではない，幼児の患者心 理の分析から始め自己認識型, 協力型と強制型に分類 し,それぞれの型に合致する視覚的映画や, Cassette tape を利用しての動物(今回は犬の泣き声)の擬音で幼児の注 意をひかせる方法で撮影整位を得ると報告している。

今後毛第 3 報と続くと思うが，㭃児，小児の好まれる 映像や色彩, 擬音の種類，または鳥類加動物の種類等の 調查研究を期待したい.

演題28は, 主として救急医療における腹部単純撮影に 限局した撮影手順について述べられている。

当然のととではあるが，その機にあって，適切な判断 こそがなにより重要と述べられている。

診断時の撮影体位は左側臥位，仰陮位，立位を基本体 位として不可欠条件としているが，適宜透視を利用する 診断もあってよいのではないかと感じた。

\section{治療}

座辰 渡部洋一（名古屋大学病院）

\section{9. 子宮頸癌に対する外照射, 腔内照射の複合照射にお ける照射方法，線量計算の検討}

静岡県立総合病院放射線部

○伊藤生也・佐藤信之

当院では Whole pelvis 外照射亡腔内照射の複合照射 を行なっている. 今回腔内照射 20 例について，その再現 性を検討し，外照射における central shild 決定の一法 を考えた。

〔結果】ラルストロン腔内照射において TANDEMで $2.0 \mathrm{~mm}$ ovoid で $4.0 \mathrm{~mm}$ の線源のズレが存在すると 想定されるままた特に ovoid のズレが大きく，再現性 は ovoidのズレによって左右されると言って良い。以 上のような結果により，当院では上記ズレがあるすのと 仮定し, central shild の寸法, 位置を第 1 回ラルストロ ン治療の際に決定している，上記方法により，患者各々 